\title{
Task Performance and Skills in IR 4.0: The Moderating Effect of Attitude
}

\author{
Oluwatoyin Muse Johnson Popoola ${ }^{* 1}$, Ayoib Che-Ahmad ${ }^{1}$, Rachael Oluyemisi Arowolo ${ }^{2}$, \\ Mazrah Malek ${ }^{1}$
}

1 Tunku Puteri Intan Safinaz School of Accountancy, Universiti Utara Malaysia

2 Department of Accounting, Chrisland University, Nigeria

\begin{abstract}
In the advent of artificial intelligence, internet of things, selfdriving vehicles, nanotechnology, renewable energy, quantum computing, and biotechnology has taken centre stage. New markets will emerge, partly or wholly displacing others that will require new skill sets for employment and transform how and where people work. Thus, the skills required in both old and new occupations are bound to change in a specific working environment and transform how and where people work. The objective of this study is to examine the moderating impact of attitude (ATT) on skills (SK) and task performance fraud risk assessment (TPFRA) of professional accountants conceptually. This study possesses the capacity to impact the ethical, legal, regulatory, and institutional framework. Furthermore, the study possesses the abilities to persuade the efficient and effective policy formulations and enhance capacity building of the workforce in the public sector. To the best of the researchers' knowledge, this may perhaps be the first conceptual study on the accountant's attitude as an indispensable capability requirement for skills and task performance fraud risk assessment in the specific working environment.
\end{abstract}

Keywords: Attitude, skills, task performance fraud risk assessment, professional accountants, moderator

JEL Classification: M4, M10, M40, M41, M42, M48, M49

Paper Type: Research 


\section{INTRODUCTION}

The fourth industrial revolution has brought into limelight new and improved capabilities and competencies in task performance in a specific working environment. With the new wave of automation technology gearing up to replace humans in both industries and offices, and to avoid disruptions of future activities, there are necessities to brace up and look into the challenges facing the workforce and the future of work. It may also affect female and male workers differently and change the dynamics of the industry gender gap. The time is ripe to introduce strategies and policies in the areas of education, innovation and workforce, given that smart robots will take over some jobs and jobs not currently in existence will be in hot demand. Hence, the motivation to unravel or fashion out models about capabilities and competencies required for an effective, efficient and value for money specific working environment in developing countries. This paper, therefore, seeks to dig deep into the niche areas of skill sets and attitude as essential allies in the industrial revolution and to examine the moderating impact of attitude on the new skills and task performance fraud risk assessment in the working environment.

The transition to the fourth industrial revolution demonstrates the stacked realities in terms of enhanced capabilities and competencies in any working environment. It is crystal clear that the new wave of automation technology can to a certain degree replace humans in both industries and offices. To avoid disruptions of future activities, there are necessities to brace up and look into the challenges facing the workforce and the future of work. Bearing in mind the vacuum that might likely surface regarding economies and workforce in the next few years, it is imperative to put in place policies and plans to help individuals and possibly businesses to maximise to the fullest advantage the opportunities that come with the technologies or the opportunities the technologies could offer. New categories of jobs will emerge, partly or wholly displacing others.

The significant difference with the past is that today's automation technologies are highly intelligent and able to learn (Fioramonti, 2018), which suggests the rationale for humans to acquire more skills and possesses the right attitude to display high-level alignment with unrivalled performances. In the light of robotics and artificial intelligence automation driven technology, the tasks ahead for the professional accountants seem enormous to ignore, but require persuasive approach for the stakeholders to put their acts together in terms of innovation, education and strategies.

The research paper poses the following questions:

a) Do professional accountants new skills relate to task performance fraud risk assessment in the era of the fourth industrial revolution?

b) Do professional accountants attitude relate to task performance fraud risk assessment in the era of the fourth industrial revolution?

c) Does attitude (ATT) moderate the relationship between the new Skills requirements (SK) and Task performance fraud risk assessment (TPFRA) of professional accountants in the era of the fourth industrial revolution?

In the light of the questions highlighted in the preceding section, the objectives of the study are:

a) To examine the relationship between professional accountants new skills and task performance fraud risk assessment in the era of the fourth industrial revolution.

b) To examine the relationship between professional accountants attitude and task performance fraud risk assessment in the era of the fourth industrial revolution. 
c) To investigate the moderating effect of attitude on the relationship between new Skills requirements (SR) and Task performance fraud risk assessment (TPFRA) of professional accountants in the era of industrial revolution.

The study is limited to the professional accountants in the Nigerian public sector.

\section{LITERATURE REVIEW}

This section discusses the skills requirement, the attitude requirement, the concept of fraud, and the task performance fraud risk assessment of professional accountants as well as the underpinning theories of the study.

\subsection{Skills Requirement}

As far as fundamental knowledge and core skills are concerned, both the forensic accountants and auditors share common similarities. Other areas of commonalties include objective, nature, documentation, qualification, the end product, approach, and required qualities. Several studies of recent have shown that forensic accountants outclass financial statement auditors in fraud and fraud-related tasks (Popoola et al., 2015; Rose et al., 2009; Bortiz et al., 2008). Auditors may appear to exhibit a lack of sensitivity in discerning the tell-tale signs of fraud as a result of the much-publicised scandals of Enron, WorldCom and others, yet, they are in no way inferior to forensic accountants in terms of their education, training, experience, and professionalism (Popoola, Ahmad, \& Samsudin, 2013; Wuerges, 2011).

Similarly, in the recent literature on skills requirement on Future of Jobs report by the World Economic Forum (2018), 2020, 2015 skills requirements, which are arranged according to purpose and relevance in the specific working environment are:

Table 1. New Skill Sets and their Rankings in 2020, 2015 and 2010

\begin{tabular}{clll}
\hline Rank & In 2020 & In 2015 & In 2010 \\
\hline 1 & Complex Problem Solving & Complex Problem Solving & Deductive Analysis \\
2 & Critical Thinking & Coordinating with Others & Critical Thinking \\
3 & Creativity & People Management & Unstructured Problem Solving \\
4 & People Management & Critical Thinking & Investigative Flexibility \\
5 & Coordinating with Others & Negotiation & Analytical Proficiency \\
6 & Emotional Intelligence & Quality Control & Oral Communication \\
7 & Judgment and Decision & Service Orientation & Written Communication \\
& Making & Judgment and Decision & Specific Legal Knowledge \\
8 & Service Orientation & Making & Composure \\
9 & Negotiation & Active Listening & \\
10 & Cognitive Flexibility & Creativity &
\end{tabular}

From Table 1, it is clear through the ranking that skill sets keep evolving with time, events, circumstances and conditions. Complex problem-solving skills requirement has taken the first position since 2015 because of technology advancement and big data analytics. Critical thinking occupies the second position in the era of the fourth industrial revolution as against the fourth position in 2015 and second position in 2010. Similarly, creativity skills requirement that occupies the third position in 2020 used to be in the tenth position as in 2015 and second position in 2010. Coordinating with others stands in the second position in 2015 but outlived its usefulness and occupied the fifth position in 2020 . The impact in the shift is due primarily to the relevance and purpose of the skill sets required in the specific working environment. 
Furthermore, both financial statement auditors and forensic accountants are required to maintain a high degree of independence and objectivity; to be innovative; to avoid having any preconceptions and biases when evaluating evidence; to have in-depth knowledge of GAAP as well as general business practices and processes (Bologna, 1984). The issue of independence is more emphasised by the Malaysia Institute of Accountants (MIA) ByLaws (on Professional Ethics, Conduct and Practice). The Bye-Laws classified independence into two, namely: independence in mind and independence in appearance because professional scepticism is emphasised in the two categories since auditors with inquisitive minds are sceptical regarding the evidence or event, probe more in-depth until they are satisfied, or the evidence is persuasive enough to support their assertions or reject them out rightly.

Although financial statement auditors and forensic accountants share similar characteristics, the primary difference that separates them is their mission. The auditor's primary objective is to examine whether the company's reported financial statements, taken as a whole, are stated fairly in all material respects in conformity with the International Financial Reporting Standards (IFRS), the Malaysian Financial Reporting Standards (Malaysia), the Nigerian Financial Reporting Standards (Nigeria), and other local statutes. Their goal is to provide reasonable assurance that these statements are free from material misstatements (Ahmad et al., 2018; Popoola, Ahmad, \& Samsudin, 2013; Rittenberg et al., 2008).

Alternatively, a forensic accountant's primary objective is to make an absolute determination about the existence and source of fraud by gathering and evaluating evidence and interviewing all parties related to an alleged fraud situation (Hopwood et al., 2008; Singleton \& Singleton, 2007; Singleton et al., 2006).

Gerson et al. (2006) cited from Popoola (2014) offered a simple analogy to help illustrate the differences between these two professions by likening financial statement auditors to patrolmen and forensic specialists to detectives. Like auditors, patrolmen circulate through their assigned areas with the objective of keeping peace in such communities. Ideally, patrolmen would like to patrol through every location in their areas continuously. However, it would be both times and cost prohibitive for them to do so. Thus, to remain effective, patrolmen have to balance risk and expectations to determine whether to focus or expand their patrols. Unlike patrolmen, detectives do not go on patrol. They are tasked to investigate whether a crime has been committed. To accomplish their task, detectives would examine everything in the alleged crime scene to gather any clues that may help them solve the case. Crime investigation is a time consuming, and costly endeavour as detectives are expected to keep searching and piecing different clues together until they solve the crime.

In a broader sense, forensic accountants' engagements are usually geared towards finding where the money went, how it got there, who was responsible, how to look beyond the numbers and deal with the reality of business in the circumstance (Zysman, 2001). Whereas, auditors are required to perform their duties in accordance with institutional, ethical, legal and regulatory framework such as Companies \& Allied Matters Act, (CAMA) 1990, Corporate Affairs Commission (CAC) circulars, International Standards on Auditing (ISA) issued by International Federation of Accountants (IFAC) and adapted in Nigeria through Nigerian Standards on Auditing (NSAs) by The Institute of Chartered Accountant of Nigeria (ICAN), Judicial pronouncements, Statement of Accounting Standards (SAS) issued by the Nigerian Financial Reporting Council (NFRC), Central Bank of Nigeria (CBN) guidelines and circulars, National Insurance Commission of Nigeria (NAICOM) guidelines, Pension Fund Act, 2004, National Communication Commission (NCC) guidelines and circulars (Popoola, Ahmad, \& Samsudin, 2013; Popoola, 2010). 
The public sector accountant requires excellent skills to look at the evidence before him from different standpoints to recognise different possible interpretations of that evidence and the implications of those interpretations for the matter in hand. The body of forensic accounting literature that has emerged since the 1990s has mirrored the changing scope of concerns about the characteristics and skills of the forensic accountant. Some articles focused on the increasing demand for accountants to conduct forensic accounting activities and on the broadening definition of forensic accounting away from a narrow fraud detection definition (Rezaee et al., 2006).

\subsection{Attitude Requirement}

Attitude has been a source of government intelligence policy failures for several years. Analytic means for overcoming attitude or mindsets also have been long known, but bureaucratic dynamics make them surprisingly tricky to implement. One of the most promising methods for overcoming mindsets-evidence-based multiple scenario analysis - is probably best achieved in a loosely structured, networked organisation (Popoola, Ahmad, Samsudin, \& Hartini, 2013). Strategic planners and intelligence professionals, whose effectiveness depends on overcoming mindsets, face a particular challenge when they work in a bureaucratic or a hierarchical setting (Popoola, 2014; Feder, 2000).

Torelli and Kaikati (2009) posit that values are abstract representations of ideal and hence are more likely to influence behaviour when individuals think abstractly (vs concretely) and focus on high - (vs low -) level motivations for interpreting their actions. The researchers used 6 experiments to measure the importance of values (or make them salient through a priming procedure) and simultaneously manipulated accessible mindsets (abstract vs concrete), and assessed their effect on judgments and behaviours. In conclusion, their findings support the notion that values are more likely to be expressed through value-congruent judgments and behaviours when individuals think abstractly about their actions, and not when they think concretely.

Similarly, in another three experiments study performed by Brandstätter and Frank (2002) with a sample size of 243 students, the hypothesis was tested that mindsets affect goal-directed persistence in behavioural conflict situations. In Studies 1 and 2, an implemental mindset led to higher persistence as compared with a deliberative mindset in solving a puzzle or playing a computer game, respectively, when the characteristics of the task implied a behavioural conflict (i.e., when perceived desirability was low and perceived feasibility was high, or vice versa). No differences were found when the appropriateness and viability of the task were both low or both high. In Study 3, it was demonstrated that, depending on the functional value of persistence in the given situation, the implemental mindset leads to lower persistence compared with the deliberative mindset (Frank, 2010). The inferences that can be made from these findings are that the implemental mindset is a self-regulatory mechanism that permits a flexible response to the demands of a particular situation. This shows clearly that mindsets affect the behaviour of people most especially in the areas of fraud risk assessment performance judgment.

On strategic intelligence, research has shown the main difference between forensic accountants or intelligence officers on the one hand, and all other people including auditors, on the other hand, is that the former is supposed to have had more training in the techniques of guarding against their intellectual frailties (Kent, 1949), cited from Frank (2010). In addition, Runsfield (1998) cited from Frank (2010) while alluding to the effect of mindset on task performance fraud risk assessment comments that the surprise to him is not that there have been and will continue to be surprises, but that the group is surprised that there are surprises, and therefore agrees with Von Clausewitz assertion which states that "the unexpected is the prince of the battlefield". Given the importance of attitude to 
task performance and quoting the words of McLaughlin John (2001) cited from Popoola, Che-Ahmad, and Shamsudin (2014). George (2004) in his study "fixing the problem of analytical mindsets: alternative analysis" expresses his everyday consciousness of how important it is for analysts to challenge the conventional wisdom to separate what they know from what they merely think and to consider alternative outcomes. He argues that the best alternative of assessing fraud risk is not to fall victim to a mindset, over-confidence or anyone pet paradigm.

Undoubtedly, forensic accountant thinking is based on the authenticity of events and activities relating to accounting records (Singleton \& Singleton, 2007; Singleton et al., 2006). More importantly, forensic accountants are charged with the objective to make an absolute determination about the existence of fraud (Popoola, Che-Ahmad, \& Shamsudin; 2014; Singleton \& Singleton, 2007; Singleton et al., 2006; Silvertone \& Davia, 2005; Davia, 2000).

\subsection{Fraud Concept}

The literature is replete with several concepts, and definitions of fraud and these definitions continue to evolve depending on the circumstances, conditions, and events. Fraud can be described or recognised as a premeditated act demonstrated for the purposes of deceiving, cheating, conning, and cunning an innocent or weak party, who eventually suffers a loss. In the same way, Albrecht, Albrecht, Albrecht and Zimbelman (2012) describe fraud as all deceptive ways in which one individual obtains an advantage over another by false representations. They argued that fraud entails confidence and trickery and is different from robbery where force is employed. Wells (2002), describes fraud as trickery and classifies it into two: (1) internal fraud commonly committed by employees and officers of organisations, and (2) external fraud which is perpetrated by organisations against individuals, by individuals against organisations, by organisations against organisations and by individuals against individuals. To expatiate on the concept of internal and external fraud, a banking executive filing a false report with Central Bank of Nigeria (CBN), Malaysia Bank Negara; or an insurance executive with the National Insurance Commission (NAICOM), regulatory authority is committing internal fraud. On the contrary, a customer of the same insurance company filing a false accident claim is involved in external fraud. An older adult who falls victim to telemarketing scam is caught in an external fraud.

Researchers describe fraud as a means by which a person can achieve an advantage over another by false suggestions or suppression of the truth (Popoola et al., 2015; Popoola, 2014; Keshi, 2011; Akers \& Bellovary, 2006; Singleton et al., 2006). Similarly, prior studies identify four components of an action to constitute fraud: (1) false representation of fact; (2) scienter (intention to deceive); (3) reliance; and (4) damages (Cohen et al., 2010; Skalak et al., 2006; DiGabriele, 2006; Wells, 2004; Wells, 2004b). This perhaps indicates the occurrence of fraud may likely be as a result of reliance by the victim through false representation from a perpetrator who has the deceptive intention, which led the victim to incur severe damages.

\subsection{Fraud Risk Assessment}

In the course of an audit engagement, auditors are expected to carry out a normal audit which involves performing procedures to obtain audit evidence about the amounts and disclosures in the financial statements. According to International Standard on Auditing (IAS) No 240, The Auditor's Responsibilities Relating to Fraud in an Audit of Financial Statements, it is the responsibility of the auditors to select appropriate procedures based 
on the auditor's judgment, including the assessment of the risks of material misstatement in the financial statements, whether due to fraud or error. In making those risk assessments, the auditor considers internal control relevant to the entity's preparation and fair presentation of the financial statements in order to design audit procedures that are appropriate in the circumstances, but not for the purpose of expressing an opinion on the effectiveness of the entity's internal control (Ahmad, Haron, Malik, Salleh, Hariri, Khan \& Nelson, 2018; IFAC., 2010; PCAOB, 2007).

This study focuses on the task performance of individuals in the wave of the fourth industrial revolution in the specific working environment. It is evident that fraud risk assessment has a direct impact on the auditors' ability to detect fraud because it is the bedrock of the audit. It helps the auditors to determine the extent and nature of subsequent audit procedures. Given the complexity of fraud risk assessments, auditors' lack of fraudrelated experience, and auditors' impoverished capability for assessing fraud relative to deterministic models, auditors commonly employ fraud risk assessment decision aids in practice (Allen et al. 2006). The appendix of Statement on Auditing Standard (SAS) No. 99, Consideration of Fraud in a Financial Statement Audit, provides a checklist decision aid for use in practice (AICPA 2002). However, in the words of Nieschwietz et al. (2000) fraud detection has created a significant challenge for the auditing profession. This claim was made after reviewing 35 empirical studies; the breakdown is as follows:

"Eight (8) Studies on Fraud predictors (effectiveness of red flags in predicting fraud); Eleven (11) Studies on unaided fraud risk assessments (how well auditors assess audit risk associated with fraud); Six (6) Studies on mechanically-aided fraud risk assessments (how well auditors assess audit risk associated with fraud when aided by checklists, expert systems, or other means); and Ten (10) Studies on audit plans and fraud detection (how audit plans are modified or not modified due to increased risk of fraud)".

Also, this study supports the clarion call on all accounting researchers to continue in their search for ways to improve fraud risk assessment performance as auditors are not trained to prevent, detect, deter and remediate fraud and other white-collar crimes.

\section{Red Flags}

Fraud is not an openly visible crime. Hence, it is difficult to detect by observers that are not trained (Albrecht et al., 2012; Davia, 2002). It can be discovered only through "red flags", which supports the notion of compromise of ethics and honesty within an organisation. Such as red flags can be from the accounting system, lack of segregation of duties and other crucial internal control features, lack of integrity in top management behaviour, unusual or extravagant behaviour on the part of employees, and numerous complaints or hotline tips. All these are indicators that fraud may exist - not necessarily proof of fraud.

Red flags as indicators to fraud are very crucial in fraud risk assessment since they afford auditors with indications about the possible existence of fraud (Singleton et al., 2006). Previous research has shown that the use of red flag questionnaires gives auditors a structured approach to the consideration of fraud in an audit and also increase awareness to the possibility of fraud, thereby improve the likelihood of detecting fraud (Krambia-Kapardis, 2002).

The emphasis on fraud detection gradually went down from 1933 to 1940 (Albrecht et al., 2001; Brown, 1962). Long before the Enron debacle, the audit profession was confronted with the infamous McKesson and Robbins scandal in late 1938. According to 
Carey (1939), McKesson and Robbins scandal was "like a torrent of cold water" that "shocked the accountancy profession into breathlessness (as cited from Wuerges, 2011)".

Similarly, according to International Standards on Auditing (IAS) issued by International Auditing \& Assurance Standards Board (IAASB) of the International Federation of Accountants (IFAC), Nigerian Standards on Auditing (NSA) published by the Institute of Chartered Accountants of Nigeria (ICAN), and Malaysian Standards on Auditing issued by the Malaysia Institute of Accountants, auditor's responsibility on the financial statements is solely to express an opinion on the audit which must be conducted in accordance with relevant standards, that is, ISAs. These standards require that auditors comply with ethical requirements and plan and perform the audit in such a manner as to obtain reasonable assurance whether the financial statements are free from material misstatement. It will, therefore, be inappropriate and a misnomer to argue that the responsibility for fraud detection still rests on the auditors.

On the contrary, the responsibility to prepare a financial statement by GAAP and International Public Sector Accounting Standards (2012) rest with the management of the organisation. In performing this responsibility, management is expected to include designing, implementing and maintaining internal control relevant to the preparation and fair presentation of financial statements that are free from material misstatement, whether due to fraud or error; selecting and applying appropriate accounting policies; and making accounting estimates that are reasonable in the circumstances (Ahmad et al., 2018; Popoola, 2014; IAASB, 2010).

This study is aimed at integrating forensic accounting skills and attitude into the conduct of the audit as researchers argue that forensic accountants are more effective in the assessment of fraud risk than the auditors (Popoola et al., 2015; Popoola, 2014; Wuerges, 2011).

\subsection{Underpinning Theory}

\subsubsection{Health Belief Model (HBM)}

The HBM is a health-specific social cognitive model which has adapted theories from behavioural sciences (Ajzen, 1998). The unique HBM was developed to appreciate the decision to use preventive health services in the public health system (Hochbaum, 1958). The purpose of HBM is to create awareness and consequently increase the use of public health services such as vaccines and screening programmes. Previous research has shown that the model is extensively used and widely recognised to predict protective health behaviours and health services use (Abraham \& Sheeran, 2005). The primary constructs of HBM are perceived severity, susceptibility, benefits, and risks (Rosenstock 1974). Findings of previous studies suggest that each construct of the HBM is a significant predictor for protective health behaviour (Harrisson, Mullen, \& Green 1992; Janz \& Becker 1984). According to Muthusamy, Quaddus and Evans (2010), the behaviour to prevent and detect fraud is comparable to the behaviour to prevent and screen for illness. The motivation to contrast forensic accountant and auditor in the public sector in Nigeria and protective health services arises from the same expectation that this action can reduce the likelihood or severity of harm. However, since this study is based on organisational task performance, the limitation of this HBM is the lack of consideration on normative and external factors. 


\subsubsection{Theory of Planned Behaviour (TPB)}

The TPB is an extension of the Theory of Reasoned Action (TRA) (Ajzen \& Fishbein, 1980; Fishbein \& Ajzen, 1975) which only included the first two components of the model: (1) attitude, and (2) subjective norms. According to Cohen, Ding, Lesage \& Stolowy (2010) and Hess (2007, p.1784), the TPB is a "parsimonious model but has significant power in explaining variations in intentions. The simplicity of the model also makes it useful for understanding and explaining the various studies that have been conducted on ethical behaviour in organisations". TPB is handy to predict evasive or dishonest actions (Beck \& Ajzen, 1991). As noted by Al-Qeisi (2009), TPB addresses the issue of behaviours that occur without a person's volitional control, and it differs from the theory of reasoned action because of the inclusion of perceived behavioural control (PBC). This component accounts for situations where an individual has less than complete control over the behaviour. This can vary across situations and actions (Ajzen, 1991).

As noted by Ajzen (2006), the TPB deals with the antecedents of attitude, subjective norms and perceived behavioural control and hence postulates that behaviour is a function of salient beliefs relevant to that behaviour. These beliefs are (1) behavioural beliefs, (2) normative beliefs, and (3) control beliefs. Carpenter and Reimers 2005) find with a survey analysis and an experiment, that the TPB can help explain unethical and fraudulent financial reporting.

Models such as the theory of reasoned action (TRA) and the theory of planned behaviour (TPB) are not without limitation. Even though TPB came in as a replacement of TRA given its volitional control limitation which suggests behaviours are deliberate and planned, yet TPB does not show how do people plan and how does planning mechanism relate.

\section{CONCEPTUAL AND THEORETICAL FRAMEWORK}

The conceptual framework of the study based on the variables of skill sets, attitude and task performance fraud risk assessment is illustrated in Figure 1.

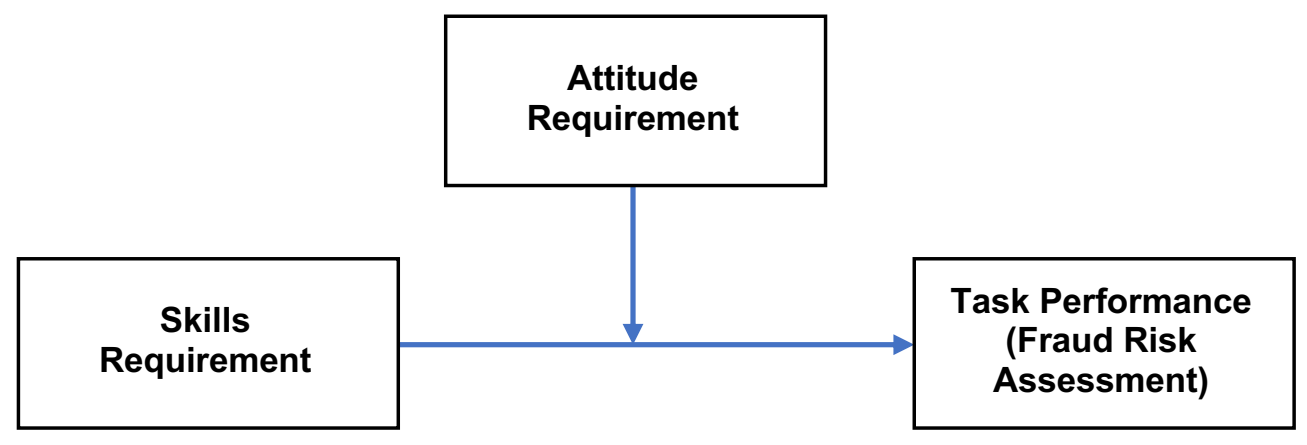

Figure 1. Conceptual Framework of Skills, Attitude and Task Performance Fraud Risk Assessment

Similarly, the theoretical framework of the study, which represents the statistical diagram or hypotheses development of the relationship between variables and differences among the groups, (that is, the forensic accountant and auditor) are shown in Figure 2. 


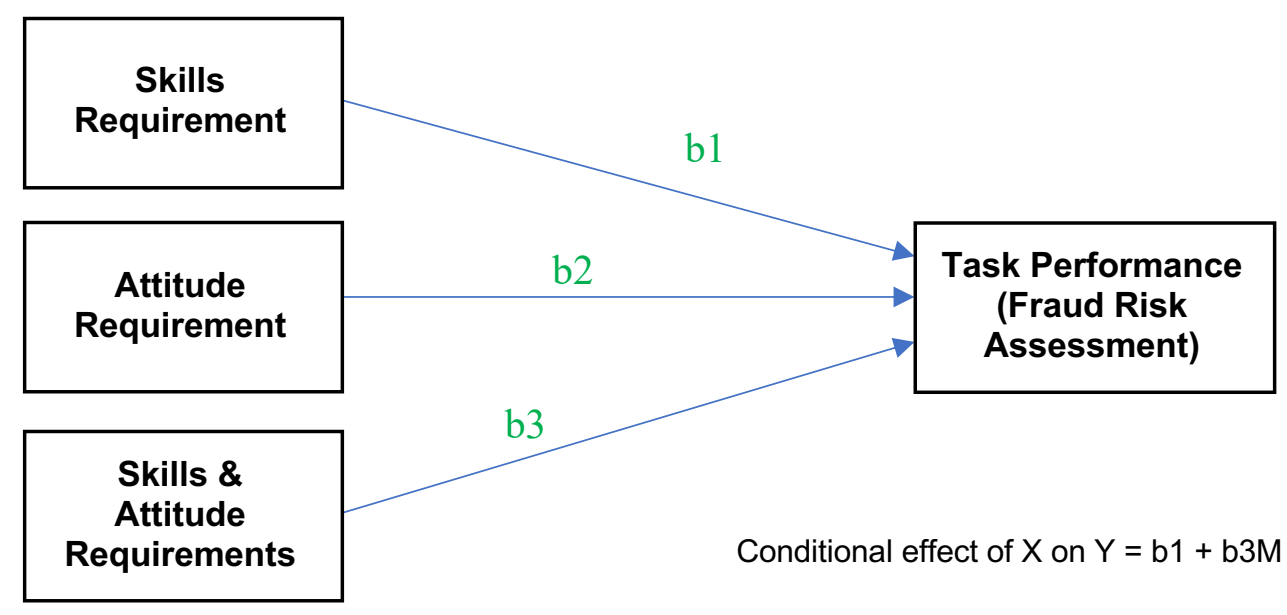

Figure 2. Theoretical Framework of the Skills, Attitude and Task Performance Fraud Risk Assessment

\section{HYPOTHESIS DEVELOPMENT}

The first theoretical linkage in this research framework represents the prediction that skill sets and attitude of accountants have a direct impact on task performance fraud risk assessment. Based on prior literature, a simple difference in skills and attitude can yield substantial performance differences as well as impact individuals' confidence, determination, and commitment to accomplish decision making task (Popoola, 2014; Chui, 2010; Brandstatter and Frank, 2002; Gollwitzer, 1989). Previous research has shown through experiment that forensic accountant or fraud specialists are more sensitive and better able than auditors in discerning and discovering fraud in an audit when fraud is present (Boritz et al., 2008). Thus, it is hypothesised that:

$H_{1}$ There is a significant positive relationship between the new skills of a professional accountant and task performance fraud risk assessment in the era of the fourth industrial revolution.

$\mathrm{H}_{2}$ There is a significant positive relationship between the attitude of a professional accountant and task performance fraud risk assessment in the era of the fourth industrial revolution.

In the context of this study, professional accountant skills and attitude differ regarding purpose, frequency, scope and objective of the task in the specific working environment. For instance, Forensic accountants are to carry out in-depth investigation and to decide whether fraud exists, the perpetrators, and remedial action. Auditors are to determine the truth and fairness of reported financial statements taken as a whole. In essence, auditors are required to exercise professional scepticism - in mind and appearance - in their consideration of fraud as they have been criticised for being creatures of habit and are not good at thinking outside the box (Popoola, 2014; PCAOB, 2007).

Given the skills and task performance fraud risk assessment competency, this study affirms that professional accountants task judgement in a specific working environment differs if attitude interacts with the relationship between skills and task performance fraud risk assessment. In essence, while individuals who are primed with a forensic accountant 
skill set and attitude are more likely than individuals with auditor skills and attitude to assess fraud risk effectively in the high fraud risk condition, may be less effective in their assessment of the lowest fraud risk condition. Also, that forensic accountant attitude is significant than auditor attitude in fraud risk assessment task performance (Popoola, 2014; Chui, 2010). Thus, it is hypothesised that:

$\mathrm{H}_{3}$ Attitude, as a capability requirement, moderates the relationship between professional accountants skills and task performance fraud risk assessment in the era of the fourth industrial revolution

\section{CONCLUSION}

The study develops several hypotheses concerning skill sets, attitude and task performance fraud risk assessment based on the research objectives. This study provides a detailed discussion of the linkage between skills and task performance fraud risk assessment, and the relationship between attitude and task performance fraud risk assessment. Furthermore, the attitude interaction effect is crucial to the study as it ties the impact of professional accountant skills to the task performance fraud risk assessment literature.

\section{REFERENCES}

Abraham, C. \& P. Sheeran. (2005). The health belief model. In Predicting health behaviour: Research and Practice with Social Cognition Models eds. M. Conner and P. Norman, 2nd ed., 28-80 Buckingham, UK: Open University Press.

Ahmad, C. A., Haron, H., Malik, M., Salleh, Z., Hariri, H., Khan, N. I., \& Nelson, S. P. (2018). Fundamentals of auditing. Oxford University Press, Malaysia.

Ajzen, I. (1998). Models of human social behaviour and their application to health psychology. Psychology \& Health, 13(4), 735-739.

Ajzen, I. \& Fishbein, M. (1980). Understanding Attitudes and Predicting Social Behavior. Englewood Cliffs, NJ: Prentice-Hall.

Al-Qeisi, K. I. (2009). Analysing the use of the UTAUT model in explaining an online behaviour: Internet banking adoption. PhD thesis. Brunel University.

Aizen, I. (2006) Theory of planned behaviour [Internet] Available from http://www.people.umass.edu/aizen/tpb.diag.html. Retrieved July 18, 2014.

Ajzen, I. (2006). Constructing a TPB questionnaire: Conceptual and methodological considerations. Retrieved November 7, 2012.

Akers, M. D., \& Bellovary, J. L. (2006). What is Fraud and Who is Responsible? Journal of Forensic Accounting, 7, 247-256.

Albrecht, C. C., Albrecht, W. S., \& Dunn, J. G. (2001). Can Auditors Detect Fraud: A Review of the Research Evidence Journal of Forensic Accounting, 2, 1-12.

Albrecht, W. S., Albrecht, C. O., Albrecht, C. C., \& Zimbelman, M. F. (2012). Fraud Examination. $4^{\text {th }}$ Edition. South Western Cengage Learning. USA.

Allen, R. D., Hermanson, D. R., Kozloski, T. M., \& Ramsay, R. J. (2006). Auditor Risk Assessment) Insight from the Academic Literature, Accounting Horizons, 20(2), 157-177.

American Institute of Certified Public Accountants. (2002). Statement on Auditing Standards (SAS) No. 99, Consideration of Fraud in a Financial Statement Audit (AICPA, Professional Standards, vol. 1, AU sec. 316.50), American Institute of Certified Public Accountants.

Beck, L., \& Ajzen, I. (1991). Predicting Dishonest Actions Using the Theory of Planned Behaviour, Journal of Research in Personality, 25(3), 285-301.

Bologna, G. J. (1984). Corporate Fraud: The Basics of Prevention and Detection. Stoneham, MA: Butterworth Publishers. 
Boritz, J. E., Kotchetova, N., \& Robinson, L. A. (2008). Planning Fraud Detection Procedures: Fraud Specialists vs Auditors Working Paper: University of Waterloo.

Brandstatter, V., \& E. Frank. (2002). Effects of Deliberative and Implemental Mindsets on Persistence in Goal-directed Behavior, Personality and Social Psychology Bulletin, 28(10), 1366-1378.

Carpenter, T. D. \& Reimers, J. L. (2005). Unethical and Fraudulent Financial Reporting: Applying the Theory of Planned Behavior. Journal of Business Ethics, 60, 115-129.

Chui, L. (2010). An experimental examination of the effects of fraud specialist and audit mindsets on fraud risk assessments and the development of fraud-related problem representations.

Cohen, J., Ding, Y., Lessagem C., \& Stolowy, H. (2010). Corporate Fraud and Managers' Behavior: Evidence from the Press. Journal of Business Ethics.

Davia, H. R. (2000). Fraud 101: Techniques and Strategies for Detection. New York, NY: John Wily and Sons, Inc.

Davia, H. R. (2002). Fraud Specific Auditing. The Journal of Forensic Accounting, 3, 111-120.

Davies, C., Farrell, N., \& Ogilby, S. (2009). Characteristics and skills of the Forensic Accountant. American Institute of Certified Public Accountants FVS section.

DiGabriele, J. A. (2006). Divorce and the self-employed meet economic reality. Journal of Forensic Accounting, 7(2), 38-44.

Feder, S. A. (2000). Overcoming mindsets: What corporations can learn from government intelligence failures. Competitive Intelligence Review, 11(3), 28-36.

Fioramonti, L. (2018). Global automation readiness. Who's prepared, who's in trouble? Retrieved on 28 September 2018 from https://www.zdnet.com/article/global-automation-readinesswhos-prepared-whos-in-trouble/

Fishbein, M., \& Ajzen, I. 1975. Belief, Attitude, Intention and Behavior: An Introduction to Theory and Research. Reading, MA: Addison-Wesley.

George R. Z. (2004). Fixing the Problem of Analytical mindsets: Alternative Analysis. International Journal of Intelligence and Counterintelligence, 17, 385-404

Gerson, J. S., Brolly, J. P., \& Skalak, S. L. (2006). The Roles of the Auditor and the Forensic Accounting Investigator In Golden, T. W., S. L. Skalak, and M. M. Clayton. (Ed.), A Guide to Forensic Accounting Investigation (pp. 243-257). Hoboken, NJ: John Wiley \& Sons, Inc.

Gollwitzer, P. M. (1990). Action Phases and Mind-Sets In Higgins, E. T., and R. M. Sorrentino. (Ed.), Handbook of Motivation and Cognition: Foundations of Social Behavior. (Vol. 2, pp. 5392). New York, NY: Guilford Press.

Harrison, J. A., Mullen, P. D. \& Green, L. W. (1992). A meta-analysis of studies of the Health Belief Model with adults. Health Education Research, 7(1), 107-116.

Hess, D. (2007). A Business Ethics Perspective on Sarbanes-Oxley and the Organizational Sentencing Guidelines', Michigan Law Review, 105(8), 1781-1816.

Hochbaum, G. M. (1958). Public Participation in Medical Screening Programs: A Sociopsychological Study. PHS Publication No. 572, Government Printing Office, Washington, DC.

Hopwood, W. S., Leiner, J., \& Young, G. R. (2008). Forensic Accounting. New York, NY: McGrawHill/Irwin. http://www.acfe.com/about/press-release.asp?copy=10-12-2005

Keshi, O. N. (2011). Nature and Taxonomy of Fraud. Institute of Chartered Accountants of Nigeria Forensic Audit \& Investigation Faculty.

Krambia-Kapardis, M. (2002). A Fraud Detection Model: A Must for Auditors. Journal of Financial Regulation and Compliance, 10(3), 266-278.

Nieschwietz, R. J., Schultz, J. J., \& Zimbelman, M. F. (2000). Empirical Research on External Auditors' Detection of Financial Statement Fraud. Journal of Accounting Literature, 19, 190246.

Popoola, O. M. J., Che-Ahmad, A., \& Samsudin, R. S. (2015). An empirical investigation of fraud risk assessment and knowledge requirement on Fraud related problem representation in Nigeria. Accounting Research Journal, 28(1), 78 - 97. doi: http://dx.doi.org/10.1108/ARJ-082014-0067

Popoola, O. M. J. (2014), Forensic accountants, auditors and fraud: capability and competence requirements in the Nigerian public sector", A thesis submitted to the Othman Yeop Abdullah 
Graduate School of Business, Universiti Utara Malaysia, in fulfilment of the requirement for the Degree of Doctor of Philosophy, Malaysia.

Popoola, O. M. J., Ahmad, A.C. \& Samsudin, R.S. (2013), Forensic accounting knowledge and skills on task performance fraud risk assessment: Nigerian public sector experience", Conference Proceedings, Okinawa.

Popoola, O. M. J., Ahmad, A.C., Samsudin, R.S. \& Hartini, A. (2013), Task performance fraud risk assessment on forensic accountant knowledge and mindset in Nigerian public sector, Conference Proceedings, Seoul.

Popoola, O. M. J., Che-Ahmad, A., \& Samsudin, R. S. (2014). Impact of Task Performance Fraud Risk Assessment on Forensic Skills and Mindsets: Experience from Nigeria. International Journal of Business and Social Science, 5(9), 216-224.

Public Company Accounting Oversight Board (PCAOB) (2007). AU Section 326. Audit Evidence.

Results, R. M. (2017). The skills you need for the fourth industrial revolution. Retrieved on 21 September 2018 at https://rmresults.co.uk/blog/the-skills-you-need-for-the-fourth-industrialrevolution

Rezaee, Z., Crumbley, L. D., \& Elmore, R. C. (2005). Forensic accounting education: A survey of academicians and practitioners. In Advances in Accounting Education: Teaching and Curriculum Innovations, eds. B. N. Schwartz and J. E. Ketz, 193-231. Greenwich, CT: Jai Press.

Rezaee, Z., \& Riley Jr., R. A. (2010). Financial Statement Fraud: Prevention and Detection. 2nd edition. New York, NY: Wiley.

Rittenberg, L. E., Schwieger, B. J., \& Johnstone, K. M.. (2008). Auditing: A Business Risk Approach. 6th ed. Mason, $\mathrm{OH}$ : Thomson Higher Education.

Rose, J., M., B. McKay, \& C. S. Norman. (2009). Designing Decision Support Systems to Promote the Acquisition of Expertise Working Paper: Southern Illinois University Carbondale.

Rosenstock, I. M. (1974). Historical origins of the Health Belief Model. Health Education Monographs 2: 328-335.

Silverstone, H., \& Davia, H. R. (2005). Fraud 101: Techniques and Strategies for Detection. 2nd ed. Hoboken, NJ: John Wily and Sons, Inc.

Singleton, T. W., Singleton, A. J. , Bologna, G. J., \& Lindquist, R. J. (2006). Fraud Auditing and Forensic Accounting. 3rd ed. Hoboken, $\mathrm{NJ}$ : John Wiley and Sons, Inc.

Singleton, T. W., \& A. J. Singleton. (2007). Why Don't We Detect more Fraud? Journal of Corporate Accounting and Finance 18(4), 7-10.

Skalak, S. L., Alas, M. A., \& Sellitto, G. (2006). Fraud: An Introduction In Golden, T. W., S. L. Skalak, and M. M. Clayton. (Ed.), A Guide to Forensic Accounting Investigation (pp. 1-20). Hoboken, NJ: John Wiley and Sons, Inc.

The Institute of Chartered Accountants of Nigeria (2009), Public Sector Accounting Study Pack. VI Publishers, Lagos, Nigeria

Torelli, C. J., \& Kaikati, A. M. (2009). Values as Predictors of Judgments and Behaviors: The Role of Abstract and Concrete Mindsets. Journal of Personality and Social Psychology, 96(1), 231247.

Wells, J.T. (2005), Accountants need help fighting the war on fraud; ACFE founder urges antifraud Education Press Release], from the Association of Certified Fraud Examiner, available at www.acfe.com/about/press-release.asp?copy10-12-2005 (accessed 13 November 2012).

Wells, J. T. (2004). New Approaches to Fraud Deterrence. Journal of Accountancy, 197(2), 72-76.

Wells, J. T. (2004b). Corporate Fraud Handbook: Prevention and Detection. Hoboken, NJ: John Wiley and Sons, Inc.

Wells, J. T. (2002). Ghost Goods: How to Spot Phantom Inventory. Journal of Accountancy, 191(6), 33-36.

Wuerges, A. (2011), Auditors' responsibility for fraud detection: new wine in old bottles?, available at: www.scribd.com/doc/63671899/Auditors-Responsibility-for-Fraud-Detection (accessed 3 November 2012). 